\title{
Analisis Kemampuan Pembiayaan Keuangan Pemerintah Provinsi Aceh Setelah Penerapan Revisi UU Tentang Otonomi Daerah
}

\author{
Almira Keumala Ulfah ${ }^{1}$, Dedy Fernanda ${ }^{2}$, Rahmaniar $^{1}$, Sisca Mediyanti $^{1}$, Agustina $^{3}$, Azlina $^{3 *}$, Arie Andina $^{1^{*}}$ \\ ${ }^{1}$ Program Studi Diploma III Akuntansi, Politeknik Kuta Raja, Banda Aceh, Indonesia \\ ${ }^{2}$ Fakultas Ekonomi, Universitas Syiah Kuala, Banda Aceh, Indonesia \\ ${ }^{3}$ Program Studi Diploma IV Analisis Keuangan, Politeknik Kuta Raja, Banda Aceh, Indonesia \\ Email: ${ }^{1}$ almirakeumalaulfah@gmail.com, ${ }^{2}$ dedy.fernanda@yahoo.co.id, ${ }^{3}$ rahmaniar233@gmail.com, \\ ${ }^{4}$ sisca.andra@gmail.com, ${ }^{5}$ tintun3185@gmail.com, ${ }^{6 *}$ azlinazto@yahoo.com, ${ }^{7 *}$ arieandina@ @oltekkutaraja.ac.id
}

\begin{abstract}
Abstrak
Tujuan penelitian ini adalah untuk mengetahui kinerja keuangan Pemerintah Provinsi Aceh setelah diterapkannya revisi UU tentang otonomi daerah, UU no. 32 dan 33 tahun 2004 selama tahun anggaran 2005-2009 dilihat dari rasio Kemampuan Pembiayaan.Penelitian ini dilakukan pada Pemerintah Provinsi Aceh (Pemerintah Aceh). Penelitian ini menggunakan data primer yaitu : data yang secara langsung diperoleh dari Pemerintah Aceh mengenai data keuangan yang digunakan untuk mengukur kinerja keuangan yakni data laporan keuangan Pemerintah Aceh dalam bentuk laporan Anggaran Pendapatan dan Belanja Aceh (APBA) dan laporan Realisasi Anggaran Pendapatan dan Belanja Aceh (RAPBA) selama lima tahun (2005-2009). Analisis data dilakukan menggunakan metode kualitatif yang bersifat deskriptif. Tujuan yang ingin dicapai dalam penelitian ini adalah untuk mengetahui bagaimana kinerja keuangan Pemerintah Aceh setelah diterapkannya revisi UU tentang otonomi daerah, UU No. 32 dan 33 tahun 2004. Hasil umumnya menunjukkan perbedaan yang signifikan dalam pencapaian kinerja keuangan Pemerintah Aceh setelah otonomi daerah. Kinerja keuangan diukur dengan rasio keuangan. Untuk rasio kemampuan pembiayaan, kinerja keuangan Pemerintah Aceh menunjukkan hasil yang belum stabil karena masih memiliki prosentase naik dan turun terhadap hasil perhitungan, rasio efektivitas kurang efektif dan rasio efisiensi menunjukkan kinerja keuangan yang efisien karena Pemerintah Aceh, berhasil merealisasikan pendapatan asli daerah yang tinggi dengan biaya yang kecil.
\end{abstract}

Kata Kunci: Regional Autonomy, Financial Performance, and Ratio of Financing Capabilities.

\section{PENDAHULUAN}

Dalam persaingan yang terbuka dan kompetitif sebagai dampak dari globalisasi, pembangunan yang mendorong pertumbuhan perekonomian suatu negara menjadi sesuatu yang sangat penting. Pertumbuhan ekonomi tentunya membutuhkan indikator yang jelas sehingga dapat tergambarkan pasang surutnya perekonomian sebuah negara [1]. Reformasi keuangan daerah di Indonesia telah terjadi ditandai dengan diberlakukannya UU No. 22, Tahun 1999 tentang Pemerintahan Daerah dan UU No. 25, Tahun 1999 tentang Perimbangan Keuangan antara Pemerintahan Pusat dan Daerah. Reformasi keuangan tersebut merupakan titik tolak bagi pemerintah untuk meninggalkan sistem pemerintahan yang tersentralisasi menuju sistem pemerintahan baru yang terdesentralisasi. Era reformasi saat ini memberikan peluang bagi perubahan paradigma pembangunan nasional dari paradigma pertumbuhan menuju paradigma pemerataan pembangunan secara lebih adil dan berimbang. Perubahan paradigma ini antara lain diwujudkan melalui kebijakan otonomi daerah dan perimbangan keuangan pusat dan daerah. Dalam perkembangannya, kebijakan otonomi daerah melalui UU No. 22 tahun 1999 dinilai, baik dari segi kebijakan maupun segi implementasinya, terdapat sejumlah kelemahan. Oleh karena itulah kebijakan tersebut mengalami revisi yang akhirnya menghasilkan UU No.32 tahun 2004 tentang pemerintah daerah [2]. Seiring direvisinya UU otonomi daerah tentang pemerintah daerah, UU otonomi daerah tentang perimbangan keuangan antara pemerintah pusat dan daerah UU No 25 tahun 1999 juga direvisi yang akhirnya menghasilkan UU No 33 Tahun 2004[3]. Pemerintah daerah, khususnya Aceh memiliki hak dan kewenangan yang luas untuk menggunakan sumber-sumber keuangan yang dimiliki sesuai dengan kebutuhan dan aspirasi masyarakat yang berkembang di daerah dengan arah dan tujuan yang jelas serta dapat dipertanggungjawabkan secara akuntabel dan transparan baik kepada masyarakat di Provinsi Aceh sendiri, maupun kepada pemerintah pusat yang telah membagikan dana perimbangan kepada seluruh daerah di Indonesia [4]. Sebagai pemerintah yang diserahi tugas menjalankan roda pemerintahan, pembangunan, dan pelayananan masyarakat mempunyai kewajiban menyampaikan laporan pertanggungjawaban keuangan daerahnya untuk dinilai apakah pemerintah daerah berhasil menjalankan tugasnya dengan baik atau tidak. Guna mengetahui suatu pemerintah daerah siap menjalankan otonomi daerah, dapat dilakukan dengan suatu analisis terhadap kinerja Pemerintah Daerah yang bersangkutan. Dalam mengelola keuangan daerah dapat digunakan alat penilaian berupa analisa rasio keuangan APBD. Analisa rasio keuangan APBD dilakukan dengan cara membandingkan hasil yang dicapai oleh suatu daerah dari satu periode terhadap periode sebelumnya, sehingga dapat diketahui bagaimana kecenderungan yang terjadi. Sangat disadari bahwa setiap daerah di Indonesia memiliki potensi penerimaan yang berbeda, karena adanya perbedaan potensi sumber daya, tingkat ekonomi dan karakteristik sosial budaya. Perbedaan seperti ini menjadikan hasil penelitian yang dilakukan di daerah tertentu sulit untuk menjelaskan persoalan yang sama di daerah lain. Dengan demikian, khusus untuk Provinsi Aceh perlu dilakukan penelitian tersendiri untuk mendapatkan gambaran yang relatif lebih lengkap mengenai kemampuan daerah menjadi daerah otonom. Berdasarkan uraian diatas, maka penelitian ini dilakukan untuk mengetahui sejauh mana kemampuan keuangan daerah khususnya pemerintah Provinsi Aceh dalam masa setelah diterapkannya revisi UU tentang otonomi daerah dengan menggunakan analisis rasio terhadap APBD. 


\section{METODOLOGI PENELITIAN}

Jenis penelitian yang dilakukan adalah penelitian berbentuk deskriptif, dimana penelitian ini akan menggambarkan fenomena atau karakteristik data yang tengah berlangsung pada saat penelitian ini dilakukan atau selama kurun waktu tertentu untuk menguji dan menjawab pertanyaan mengenai status terakhir dari subyek penelitian.

Untuk memperoleh data-data dan informasi yang diperlukan dalam penelitian ini, maka penelitian ini dilakukan di Kota Banda Aceh sebagai ibu kota Provinsi Aceh tepatnya di Dinas Pengelolaan Keuangan dan Kekayaan Aceh (DPKKA) yang beralamat di jalan Tgk. Nyak Arief No.120 Banda Aceh.

Dalam penelitian ini data yang dibutuhkan adalah berupa data sekunder dan data primer. Data primer dan sekunder tersebut dikumpulkan dengan teknik pengumpulan data yaitu Penelitian Lapangan (Field Research), Study Kepustakaan (Library Research), dan Teknik Dokumentasi.

Metode analisis data yang digunakan dalam penelitian ini adalah metode Kualitatif yang bersifat deskriptif yaitu : mendiskripsikan dan menganalisa data-data dalam laporan APBA dan laporan RAPBA untuk mengetahui sejauh mana kinerja keuangan Pemerintah Aceh dilihat dari rasio kemampuan pembiayaan keuangan pemerintah Aceh dalam masa otonomi daerah setelah berlakunya revisi UU no.32 dan 33 tahun 2004 tentang otonomi daerah.

\section{ANALISA DAN PEMBAHASAN}

\subsection{Analisis Kemampuan Pembiayaan Pemerintah Aceh}

Tingkat kemampuan biaya digunakan untuk menguji tingkat kemampuan pemerintah daerah dalam membiayai APBD setiap periode anggaran. Pemerintah daerah sebagai pelaksana roda pemerintahan, pembangunan, dan pelayanan masyarakat selalu dituntut untuk mandiri dalam membiayai APBDnya sendiri pada setiap periode anggaran. Semakin tinggi derajat kemampuan pembiayaan suatu daerah menunjukkan bahwa daerah tersebut semakin mampu membiayai pengeluarannya sendiri tanpa bantuan dari pemerintah pusat. Secara umum, semakin tinggi kontribusi Pendapatan Asli Daerah (PAD), maka semakin tinggi kemampuan daerah untuk membiayai pengeluarannya sendiri. Sehingga menunjukkan kinerja keuangan yang positif. Pada tahun 2005 Pendapatan Asli Daerah (PAD) Pemerintah Aceh sebesar Rp. 262.119.998.078,04 dengan pengeluaran rutin yang dikeluarkan oleh pemerintah pada tahun ini (2005) sebesar Rp. 1.857.401.664.026,00. kemampuan pembiayaan pada tahun 2005 ini mencapai 14,11\%. Dengan melihat besarnya rasio tersebut dapat diartikan bahwa pendapatan daerah yang berasal dari dalam daerah sendiri tidak sampai seperdua dari kebutuhan dana untuk membiayai kegiatan rutin pemerintah. Dengan kata lain, penerimaan daerah yang berasal dari luar daerah Pemerintah Aceh jauh lebih besar bila dibandingkan dengan penerimaan daerah yang berasal dari dalam daerah sendiri.

Hal ini menunjukkan bahwa pada tahun ini (2005) kinerja/kemampuan pemerintah yang belum mampu membiayai keseluruhan pengeluarannya. Karena dalam menutupi kekurangan dalam membiayai pengeluaran masih lebih besar dana yang bersumber dari pemerintahan yang lebih tinggi (pemerintah pusat). Pada tahun 2006, rasio perbandingan antara pendapatan asli daerah (PAD) dengan pengeluaran rutin naik menjadi sebesar 24,43\%. Dengan melihat besarnya rasio tersebut dapat diartikan bahwa kontribusi pendapatan terhadap pengeluaran rutin mengalami peningkatan dari tahun sebelumnya. Sehingga menunjukkan kinerja / kemampuan pemerintah yang meningkat. Kenaikan rasio ini diakibatkan karena naiknya pendapatan asli daerah yang dihasilkan oleh Pemerintah Aceh lebih besar bila dibandingkan dengan naiknya pengeluaran rutin Pemerintah Aceh. Dengan kata lain, pada tahun 2006 Pemerintah Aceh mampu merealisasikan Penpadatan Asli Daerah yang dapat menutupi pengeluarannya. Pada tahun 2007, Kemampuan Pembiayaan Pemerintah Aceh sebesar $32,40 \%$ yang berarti mengalami peningkatan sebesar 7,97\%. Kontribusi pendapatan dalam membiayai pengeluaran rutin daerah adalah sebesar 32,40\% atau sebesar Rp, 587.487.310.959,13. Peningkatan ini disebabkan karena naiknya persentase dari penerimaan pemerintah yang bersumber dari pendapatan asli daerah dan menurunnya persentase pengeluaran rutin pemerintah pada tahun sebelumnya. Pada Tahun ini Pemerintah Aceh mampu merealisasikan Pendapatan Asli Daerah yang lebih tinggi dari tahun sebelumnya (2006), tetapi dalam menutupi pengeluarannya, kontribusi Pendapatan Asli Daerah terhadap Pengeluaran Rutin yang dihasilkan masih dibawah 50\%. Hal ini berarti, dalam menutupi kekurangan dalam membiayai pengeluaran masih lebih besar dana yang bersumber dari pemerintahan yang lebih tinggi (pemerintah pusat). Pada tahun 2008, Kemampuan Pembiayaan Pemerintah Aceh sebesar 45,94\% yang berarti mengalami peningkatan sebesar 13,54\% dari tahun sebelumnya (2007). Kontribusi pendapatan dalam membiayai pengeluaran rutin daerah adalah sebesar 45,94\% atau sebesar Rp, 716.290.964.931,10.

Peningkatan ini disebabkan karena persentase dari penerimaan pemerintah yang bersumber dari pendapatan asli daerah mengalami peningkatan. Dalam arti lain, Pemerintah Aceh mampu merealisasikan Pendapatan Asli Daerah yang tinggi dibandingakan dengan tahun sebelumnya (2007). Kemampuan Pembiayaan pada tahun 2008 ini menunjukkan bahwa Pemerintah Aceh telah berusaha semaksimal mungkin untuk menutupi pengeluarannya dari pendapatan yang berasal dari daerah sendiri. Dimana hal tersebut ditunjukkan dari besarnya rasio kemampuan pembiayaan pada tahun 2008 mendekati 50\%, yakni sebesar 45,94\% (berkisar antara 40\%-60\%). Dengan demikian, Pemerintah Aceh telah berusaha membiayai kegiatan rutin pemerintah yang bersumber dari dalam daerah sendiri. Pada tahun 2009, Kemampuan Pembiayaan Pemerintah Aceh sebesar 29,56\% yang berarti mengalami penurunan sebesar 16,38\% dari tahun sebelumnya. Kontribusi pendapatan Asli Daerah dalam membiayai pengeluaran rutin daerah adalah sebesar 29,56\% atau sebesar Rp. 735,205,788,491.03. Penurunan ini disebabkan karena persentase dari penerimaan pemerintah yang bersumber dari pendapatan asli daerah lebih kecil bila 
dibandingkan dengan peningkatan persentase pengeluaran rutin pemerintah pada tahun sebelumnya. Hal ini berarti pada tahun ini (2009) tingginya pengeluaran Pemerintah Aceh dalam melaksanakan pembangunan dan dari realisasi Pendapatan Asli Daerah yang dihasilkan masih belum mampu menutupi pengeluaran tersebut. Kemampuan Pembiayaan pada tahun 2009 ini, dimana besarnya rasio Kemampuan Pembiayaan pada tahun 2009 sebesar 29,56\% (berkisar antara 20\%-40\%) yang menunjukkan penurunan kinerja dari tahun sebelumnya (2008). Dengan demikian, Pemerintah Aceh mempunyai kemampuan kinerja yang masih kurang baik sehingga kurang mampu membiayai kegiatan rutin pemerintah yang bersumber dari dalam daerah sendiri. Hal tersebut disebabkan naiknya pengeluaran rutin Pemerintah Aceh untuk membiaya program-program dan tugas-tugas pemerintah.

\subsection{Evaluasi Terhadap Analisis Kemampuan Pembiayaan Pemerintah Aceh}

Tingkat kemampuan biaya digunakan untuk menguji tingkat kemampuan pemerintah daerah dalam membiayai APBD setiap periode anggaran. Pemerintah daerah dalam berotonomi sebagai pelaksana roda pemerintahan, pembangunan, dan pelayanan masyarakat selalu dituntut untuk mandiri dalam membiayai APBDnya sendiri pada setiap periode anggaran.Semakin tinggi derajat kemampuan pembiayaan suatu daerah menunjukkan bahwa daerah tersebut semakin mampu membiayai pengeluarannya sendiri tanpa bantuan dari pemerintah pusat. Berdasarkan penelitian yang penulis lakukan dapat dilihat bahwa, kinerja/kemampuan keuangan Pemerintah Aceh yang diukur dengan rasio kemampuan pembiayaan menunjukkan bahwa kinerja keuangan Pemerintah Aceh setelah diterapkannya revisi UU tentang otonomi daerah, UU 32 dan 33 tahun 2004 (tahun 2005-2009) kurang baik. Pemerintah Aceh dari tahun ke tahun ke tahun selama lima tahun anggaran 2005-2009 telah berusaha meningkatkan kinerja keuangannya. Yang berarti Pemerintah Aceh terus berusaha untuk mandiri dalam pelaksanaan otonomi daerah dan membiayai sendiri kegiatan pemerintahan, pembangunan dan pelayanan kepada masyarakat. Kemampuan pembiayaan Pemerintah Aceh bekisar antara 14,11\% sampai 45,94\% dengan rata-rata 29,29\%. Perkembangan Tingkat Kemampuan Pembiayaan Pemerintah Aceh setelah diberlakukannya revisi UU tentang otonomi daerah, UU No 32 dan 33 tahun 2004, dari tahun anggaran 2005 sampai 2009 dapat di lihat dari Gambar 1.

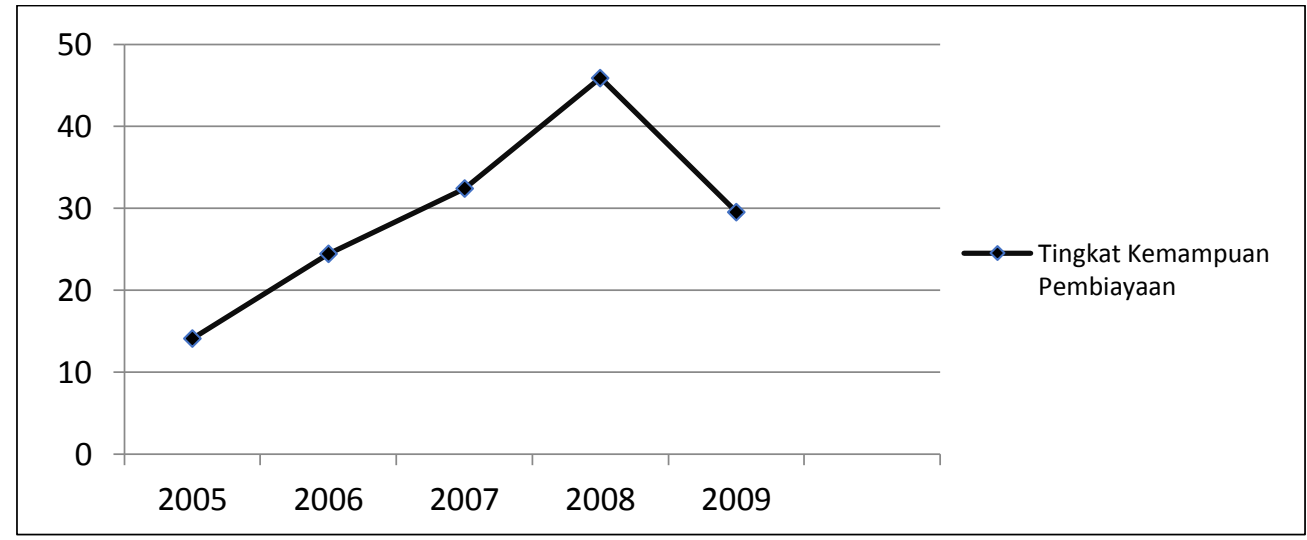

Gambar 1. Grafik Perkembangan Tingkat Kemampuan Pembiayaan Pemerintah Aceh Tahun Anggaran 2005-2009

Berdasarkan Gambar 1 dapat dilihat bahwa Pemerintah Aceh dari tahun ke tahun ke tahun selama lima tahun anggaran 20052009 telah berusaha meningkatkan kinerja keuangannya. Berarti Pemerintah Aceh terus berusaha untuk mandiri dalam pelaksanaan otonomi daerah dan membiayai sendiri kegiatan pemerintahan, pembangunan dan pelayanan kepada masyarakat. Naik turunnya kinerja keuangan Pemerintah Aceh dan memilki kinerja yang kurang baik disebabkan masih rendahnya kontribusi pendapatan dari dalam daerah sendiri (Pendapatan Asli Daerah) dalam membiayai pengeluarannya sendiri tanpa bantuan dari pemerintah pusat. Berdasarkan hal itu perlu adanya usaha untuk meningkatkan Pendapatan dari dalam daerah sendiri, yakni dengan melalui pengoptimalan sumber pendapatan yang telah ada maupun dengan mengembangkan basis pajak, meningkatkan pengumpulan pajak dan retribusi, mengoptimalkan peran BUMD, merasionalkan pengeluaran, mempromosikan kemitraan swasta-pemerintah dalam menyediakan pelayanan dan menggunakan lahan sebagai sumber daya yang penting [5].

\section{KESIMPULAN}

Berdasarkan hasil analisis data, dapat digambarkan bahwa kinerja keuangan Pemerintah Aceh setelah diterapkannya revisi UU tentang otonomi daerah, UU no. 32 dan 33 tahun 2004 masih menunjukkan rata-rata kinerja keuangan masih belum stabil atau belum begitu baik. Dimana hasil perhitungan disetiap tahun masih ada mengalami angka yang naik turun sehingga beberapa rasio keuangan masih menunjukkan kinerja yang positif dan negatif. Hal ini disebabkan oleh Pemerintah Aceh masih belum matang di dalam pengelolaan sumber daya daerah yang tersedia dan pendapatan daerah yang diterima. Kemampuan Pembiayaan Pemerintah Aceh selama lima tahun anggaran (2005 - 2009) rata-rata sebesar 29,29\%. Hal ini menunjukkan kinerja / kemampuan pemerintah yang kurang baik dengan skala kurang. Tetapi jika dilihat perkembangan Kemampuan Pembiayaan Pemerintah Aceh untuk setiap tahun anggarannya mengalami peningkatan, dikarenakan Pendapatan Asli Daerah Pemerintah Aceh setiap tahunnya mengalami peningkatan yang cukup besar. Hal ini menunjukkan bahwa Pemerintah Aceh telah berusaha mandiri dalam membiayai pengeluarannya sendiri dengan pendapatan dalam daerah 
sendiri dan mengelola keuangan daerahnya serta berusaha untuk dapat berotonomi sesuai dengan sasaran yang hendak dituju dalam otonomi daerah.

\section{REFERENCES}

[1] Supriyanto, S. (2018). Pengaruh Kinerja Keuangan Terhadap Pendapatan Saham Perbankan Di Bursa Efek Indonesia. Jurnal Bis-A: Jurnal Bisnis Administrasi, 2(1), 39-53.

[2] Undang-Undang Nomor 32 Tahun 2004 tentang Pemerintah Daerah.

[3] Undang-Undang Nomor 33 tahun 2004 tentang Perimbangan Keuangan Antara Pemerintah Pusat dan Daerah.

[4] Undang-Undang Nomor 11 Tahun 2006 tentang Pemerintahan Aceh.

[5] Undang-Undang Nomor 18 tahun 1997 tentang Pajak Daerah dan Retribusi Daerah. 